\title{
THE KEY FACTORS INFLUENCING CLIENTS' DECISION-MAKING IN THE MARKET OF SELECTED PLANNED HEALTHCARE IN THE CZECH REPUBLIC
}

\author{
- Staňková Pavla, Horkelová Jana, Lučzewská Jana, Tichá Juliana, Zimči- \\ ková Soňa, Cernobila Jan
}

\begin{abstract}
Considering the system, the economics and competitive attitudes in the healthcare market, we can certainly apply standard market tools that are usable in any competitive environment, however, with some limitations. The legal framework for the competitive healthcare services in the Czech Republic has been brought about by the privatization of the healthcare sector and private health care in accordance with Act No. 160/1992 Coll., which enabled the establishment of private health facilities. The law has also permitted clients to choose their specific healthcare establishment and their physician. On the other hand, it is also necessary to respect market specifics. A differentiated structure of health organizations is one of the main differences. Some health care organizations work as business entities and others are not-for-profit organizations whose primary objective is not profit. The type of healthcare utilized is the second difference in this environment. We can distinguish two types of healthcare: (1) acute or emergency and necessary healthcare and (2) planned healthcare. In an acute situation, involving emergency and necessary care, a client often does not take advantage of the opportunity to choose his/her healthcare provider, either due to pain or the need to solve the medical problem quickly. Regarding the planned care, a client has more time and options for choosing. Providers of planned healthcare services constitute part of a competitive environment and their task is to understand their clients' preferences and to customize their portfolio of healthcare services to meet those clients' specific needs. The purpose of the present article is to define the most important factors that influence the decision-making process of clients in the market of selected healthcare services (e.g. eye defects corrections, eyelid aesthetic treatment, orthopedic procedures, selected surgical procedures, planned childbirth and gynecological operations) and to identify the role and the importance of those factors in regard to the decision-making process. A partial aim is to find out whether there are differences in regard to the perception of the key factors that influence decision-making between men and women or between potential and real clients. The result of the research involves the evaluation of 786 questionnaires from clients or potential clients of healthcare services. They were evaluated using the Two-sample t-Test for equal means.
\end{abstract}

Keywords: healthcare, services, decision-making, acute care, planned care

JEL Classification: M31, I11, I12 


\section{INTRODUCTION}

The history of the healthcare system in the Czech lands started in 1883. At that time, the lands were influenced by both Bismarck's model of social security and the health insurance system. After World War II, Czechoslovakia fell under the Soviet influence and accepted a centralized portion of a unified healthcare system that is known as the Semashko model. The Velvet Revolution had initiated a new era of the healthcare system in the Czech Republic in 1989. (Kinkorová and Topolčan, 2012) The legal framework for privatization of health care and the emergence of a competitive environment in the Czech Republic was made by Act No. 160/1992 Coll. that covers medical care in private health facilities. Since 1992, according to the Institute of Health Information and Statistics of the CR (1992-2015), there has been a large increase in the number of healthcare organizations (from 3,965 in 1992 to 17,176 by the end of 1993).

Act No. 290/2002 Coll. that came into force on January 1, 2003, in the Czech Republic, addressed the transfer of certain other assets, rights and obligations of the Czech Republic to the Regions and the Municipalities, under which 82 district hospitals passed into the competence of the regions. These were gradually converted into joint-stock companies and by 2009 , there was a total of 52 hospitals of such kind in the Czech Republic. The third item of legislation gave scope for the application of competitive tools in the healthcare market; see Act No. 372/2011 on healthcare services and the terms for their provision. According to this law (Czech, 2011), the patient has the right to choose providers who are authorized to provide healthcare services that correspond to the health needs of the patient and the healthcare facility, and to seek consulting services from another provider or health worker who provides healthcare services. That is not the case for the provision of emergency care, nor is it applicable to persons who are in custody, in imprisonment or in security detention.

The following table presents summary information on health establishments in the Czech Republic from between 1994 and 2015.

Tab. 1 - The number of health establishments in the Czech Republic (Source: The Institute of Health Information and Statistics of the CR, 1992-2015)

\begin{tabular}{|l|l|l|l|l|l|l|l|l|l|l|l|}
\hline $\begin{array}{l}\text { Number } \\
\text { of health } \\
\text { establish- } \\
\text { ments }\end{array}$ & 1994 & 1995 & 1996 & 1997 & 1998 & 1999 & 2000 & 2001 & 2002 & 2003 & 2004 \\
\hline \begin{tabular}{l} 
Hospitals \\
\hline $\begin{array}{l}\text { Spe- } \\
\text { cialised } \\
\text { thera- } \\
\text { peutic } \\
\text { institutes }\end{array}$
\end{tabular} & 199 & 207 & 208 & 217 & 216 & 203 & 211 & 202 & 201 & 201 & 197 \\
\hline
\end{tabular}




\begin{tabular}{|l|l|l|l|l|l|l|l|l|l|l|l|}
\hline $\begin{array}{l}\text { Bal- } \\
\text { neologic } \\
\text { institutes }\end{array}$ & 51 & 55 & 51 & 51 & 56 & 53 & 63 & 67 & 68 & 82 & 83 \\
\hline $\begin{array}{l}\text { Inde- } \\
\text { pendent } \\
\text { establish- } \\
\text { ments of } \\
\text { out- } \\
\text { patient } \\
\text { care }\end{array}$ & 15767 & 17065 & 17422 & 21374 & 21626 & 21980 & 22364 & 22665 & 23060 & 23491 & 23754 \\
\hline $\begin{array}{l}\text { Special } \\
\text { health } \\
\text { establish- } \\
\text { ments }\end{array}$ & 340 & 316 & 255 & 574 & 531 & 516 & 509 & 495 & 497 & 487 & 475 \\
\hline $\begin{array}{l}\text { Estab- } \\
\text { lish- } \\
\text { ments of } \\
\text { pharma- } \\
\text { ceutical } \\
\text { service }\end{array}$ & 1322 & 1399 & 1517 & 1630 & 1714 & 1806 & 1897 & 1974 & 2075 & 2480 & 2571 \\
\hline $\begin{array}{l}\text { Organs } \\
\text { of public } \\
\text { health } \\
\text { protec- } \\
\text { tion }\end{array}$ & 90 & 86 & 86 & 86 & 90 & 86 & 87 & 87 & 86 & 30 & 30 \\
\hline \begin{tabular}{l} 
Others \\
\hline Total
\end{tabular} & 0 & 0 & 0 & 103 & 117 & 118 & 114 & 114 & 114 & 59 & 52 \\
\hline
\end{tabular}

\begin{tabular}{|l|l|l|l|l|l|l|l|l|l|l|l|}
\hline $\begin{array}{l}\text { Number } \\
\text { of health } \\
\text { establish- } \\
\text { ments }\end{array}$ & 2005 & 2006 & 2007 & 2008 & 2009 & 2010 & 2011 & 2012 & 2013 & 2014 & 2015 \\
\hline Hospitals & 195 & 191 & 192 & 192 & 191 & 189 & 189 & 188 & 188 & 189 & 187 \\
\hline $\begin{array}{l}\text { Spe- } \\
\text { cialised } \\
\text { thera- } \\
\text { peutic } \\
\text { institutes }\end{array}$ & 163 & 162 & 153 & 154 & 154 & 157 & 160 & 158 & 158 & 158 & 161 \\
\hline $\begin{array}{l}\text { Bal- } \\
\text { neologic } \\
\text { institutes }\end{array}$ & 84 & 86 & 85 & 84 & 86 & 86 & 88 & 89 & 81 & 78 & 88 \\
\hline
\end{tabular}




\begin{tabular}{|l|l|l|l|l|l|l|l|l|l|l|l|}
\hline $\begin{array}{l}\text { Inde- } \\
\text { pendent } \\
\text { establish- } \\
\text { ments of } \\
\text { out-pa- } \\
\text { tient care }\end{array}$ & 23863 & 23881 & 23955 & 24063 & 24236 & 24295 & 24542 & 24669 & 24979 & 26535 & 26862 \\
\hline $\begin{array}{l}\text { Special } \\
\text { health } \\
\text { establish- } \\
\text { ments }\end{array}$ & 472 & 446 & 431 & 417 & 407 & 391 & 383 & 383 & 368 & 361 & 355 \\
\hline $\begin{array}{l}\text { Establish- } \\
\text { ments of } \\
\text { pharma- } \\
\text { ceutical } \\
\text { service }\end{array}$ & 2646 & 2711 & 2743 & 2786 & 2813 & 2870 & 3009 & 3201 & 3379 & 3524 & 3469 \\
\hline $\begin{array}{l}\text { Organs } \\
\text { of public } \\
\text { health } \\
\text { protec- } \\
\text { tion }\end{array}$ & 30 & 30 & 30 & 30 & 31 & 31 & 31 & 19 & 19 & 19 & 19 \\
\hline Others & 35 & 33 & 39 & 43 & 41 & 49 & 48 & 46 & 46 & 50 & 47 \\
\hline Total & 27488 & 27540 & 27628 & 27769 & 27959 & 28068 & 28450 & 28753 & 29218 & 30914 & 31188 \\
\hline
\end{tabular}

The main task of healthcare organizations is to know and understand the decision-making process of the clients in the market of health services and to use the results for increasing healthcare service competitiveness.

The present article focuses on the final segment of clients and their decisions before the provision of the service. The centre of interest is the service that is called "planned care"; according to Act No. 372/2011, on healthcare services and the conditions for their provision (Czech, 2011), particularly those services that fall outside the scope:

1. emergency care, aiming to stop or limit the sudden emergence of conditions that are immediately life threatening,

2. acute care, the purpose of which is to prevent serious deterioration of health or to reduce the risk of serious health deterioration,

3. necessary care - medically required for the healthcare condition of a foreign patient, taking into account both the nature of the service and the patient's projected length of stay in the Czech Republic.

Specifics trend of healthcare service oriented on clients is introducing day surgery, which would be friendly and beneficial also for patients. As mention Soltes and Gavurova (2014), day surgery can bring highly effective treatment consisting of cured patients for the shortest possible time, without unnecessary pain and stress, but of the highest quality, without unnecessary hospital infections appearance and with as low as possible expenses. 
The main objective of the research is to define the key factors that influence the decision making process of clients in the market of selected health services and for identifying their role and their importance in the decision-making process. This article provides answers to the following questions:

- What are the key factors that influence the decision-making process in the healthcare services market?

- Is there any difference between men and women in regard to the perception of key factors?

- Is there any difference between potential and real patients in regard to the perception of key factors?

\section{THEORETICAL BACKGROUND}

The health care market is not an "ordinary" market. Patients" decision-making and choosing are closely linked to the specific arrangements that exist for funding and providing health care in each country. There are a features that particularly affect patients' choices (Dixon, et al., 2010) that are relevant to the Czech Republic's healthcare environment:

- The prevalence of third-party funding (via insurance or taxation) means that price will often not be the key factor influence on consumer choice as it is in other markets.

- Frequent regulations (either directly or indirectly) restrict consumer choice. For example, accreditation requirements that are set by the accreditation commissions restrict entry to the health and social care market to organizations that have not met the minimum quality and safety standards. Such restrictions on supply are justified as being a consequence of the informational asymmetry between health care suppliers and consumers.

- Clinical-based networks, such as those that are established for cancer care or psychiatric care, may also result in specific configurations of services and the limited availability of specialist services in some areas.

Callahan (2008) speaks about the scepticism regarding patient choice and also discusses "consumer-directed health care". He argues that the fundamental question is "whether thinking of the patient as a savvy consumer could ever make full sense in the face of complicated, emotionally charged illnesses and complex decision-making situations".

According to Leebow (2012, p. 2-3), market health service distinguishes several types of clients. The first and most important of them is the patient who is directly involved in the process of providing healthcare. The client may not be only hospitalized or an outpatient, but also the doctor who recommended the surgery. In some cases, major clients are also considered to be health insurers and payers of healthcare services. We can divide hospitals' customers into two main groups, namely the patients and the physicians who recommend healthcare procedures in a particular hospital. Similar divisions are also considered by Hunink, Weinstein et al. (2014, p. 80), who also added health insurance besides the patient and physician and the family of the patient. 
Leebow (2012, p. 2-3), besides the already mentioned groups of clients, also presents employees of healthcare organizations, which mutually cooperate and share responsibility. According to Leebow (2012, p. 2-3), the last group includes other workers in the field, for example colleagues of other organizations, social workers, representatives of health insurance companies and of other institutions. If we build on the aforementioned segmentation of customers (clients) in healthcare, this issue is also intensively described by Boyer et al. (2011, p. 233-35). He divided customer relationship management into two systems: CRM - a system of customer relationship management and PRM - a system of physician relationship management.

Models of health behaviour are closely related with clients' decisions in the healthcare services market. In practice, most widely used and most appropriate for expressing the performance and the attitudes of behaviour is The Health Belief Model. This interpersonal model assesses health behaviour of individuals and examines their perceptions and attitudes towards disease and their possible negative consequences. Burke (2009, p. 1-3) anticipates that under certain conditions, patients who are exposed to the risk of illness or to its origin based on their individual knowledge and their experience with regard to disease severity and their sensitivity of perception are willing to actively seek the support of their healthcare experts. In accordance with Henshaw (2009, p. 420-439), this model is due to a social and cognitive approach that is suitable for the use in development and evaluation of programs targeted at increasing the awareness of healthcare and disease prevention.

As reported by Leebow (2012, p. 1), the expectations of healthcare customers are not very different from those in other common services. Courtesy, honesty, respect and the quick and skilful delivery of services are what customers expect. However, there are also many factors that make health services different and unique. While other businesses can aim to make costumers happy, the main objective of health services is, of course, the curing aspect of the corresponding quality. In comparison with other types of services, extraordinary sensitivity and humanity is required as patients and their families are often both fearful and anxious. Every patient anticipates and deserves a high-quality care, attention and empathy. Many international studies clearly show that the key factor that affects client's decisions in the market of healthcare services is the quality of healthcare and of the services. Clients pursue technical factors much less and focus their attention on the level of healthcare and professional staff.

According to Dlugacz (2006, p. 5-6), people have begun to approach healthcare services in a new way. They are eager to be well-informed and to look for solutions to their healthcare problems. They are intensely interested in the most up-to-date research in the healthcare field. At present, the client is actively involved in decision making and $\mathrm{s} /$ he, therefore, requires effective and valuable means of communication.

The research team believes that it is necessary to understand the decision-making process of clients in the market and how it should affect the healthcare organization's behaviour. This approach is also confirmed by Dubey and Sharma (2013). They present 17 factors that affect the choice of hospital services through the following possibilities:

- I choose a hospital where the nursing staffs are punctual about their duties.

- I prefer the idea of a well-known and well-regarded hospital. 
- Publicity and advertisement both play an important role in the selection of a hospital.

- Agents frequently influence the patient and/or his family member(s) in regard to choosing a hospital.

- I would like my hospital to be close to where I live.

- I would like my hospital to have 24-hour outdoor services.

- I prefer hospitals where the admission process is rapid and the paper-work is minimal.

- I prefer a hospital that has an Automated Teller Machine facility on the hospital premises.

- I would prefer a hospital that uses equipment, machinery and technology that is in good condition.

- Patients are attracted by a computerized and well-equipped hospital.

- For my treatment, I would visit a hospital that has a high-quality specialist doctor.

- The doctor's approach to the patient plays a major role in the patient's return to the hospital.

- I like hospitals in which my treatment record will remain confidential.

- When selecting a hospital, I totally believe in the information of others.

- I would be likely to choose a hospital again if its basic facilities (water, electricity and the cooling system) are up-to-the-mark.

- I select a hospital that I can afford.

- I choose a hospital that has a pharmacy on/near-by the hospital premises.

Dharmesh and Devendra (2014) identified similar factors in their research that was focused on the factors that influence patients' decisions when they are selecting a hospital. The authors identified 18 most important factors: affordable prices, convenient location, the availability of emergency services, sensible promotional campaigns, a hospital with a recognised name, prior experience of the hospital, a positive word-of-mouth recommendation, qualified and experienced doctors, well-trained nursing staff, the explaining of health problems and treatments, courteous and friendly supportive staff, coverage under insurance, minimal waiting time, convenient hours, a rapid-response system, modern equipment and labs, a sound infrastructure and physical environment and a built-in pharmacy facility.

Despite the fact that both of the studies (Dharmesh and Devendra, 2014 and Dubey and Sharma, 2013) were carried out in a different environment, especially in terms of access and of private sector development, we can indubitably state that most of the factors that influence patients' choices are universal, regardless of these specific details.

A very important study that was published by Victoor, Delnoij, Friele and Rademakers (2012) carried out a wide-scoped review that described the findings and research concerning patients' choices from a wide range of healthcare providers in detail. This research was carried out on the 17th of August 2011. The databases that were used were Embase, Medline and PubMed, and they included scientific papers from 1995 and onwards. After concluding the selection process, they 
found that there were118 studies focused on the health care market and patients' choice. The main results from this research are as follows:

- according to several studies, relatively few patients actively choose their own healthcare provider, while a substantial portion of the patients does not consider the choice to be very important;

- patients do not make rational choices, as they would need complete information, unrestricted cognitive abilities, consistent preferences, willpower and the ability to foresee their needs to do so; several studies suggest that these conditions are rarely satisfied and consequently, most patients are unable to make a completely rational choice, which results in choices being made based on only some of the provider characteristics and/or on irrelevant factors (such as their current mood) and often they make no choice at all;

- in their decision-making processes, patients use a variety of information sources;

- from the processes aspect perspective, five factors can be distinguished; comprising interpersonal factors, the availability of information, the continuity of treatment, waiting time and the quality of the treatment itself.

However, the articles that are presented in the research journals do not usually deal with any different approaches to the decision-making processes from the gender point of view nor in regard to the differences between potential and real patients. There are some studies that are focused on identifying the gender differences during health care. Arora and McHorney (2000) analysed determinants of patient preferences for participation in medical decision-making. Karlson et al. (1997) present gender differences as patient preferences in regard to the utilisation of elective surgery with the main emphasis on studying gender-specific preferences regarding timing of the elective total joint replacement surgery for patients with moderately severe osteoarthritis of the hip(s) or the knee(s).

According to a systematic literature review, there are significant gaps in the research evidence concerning both men's and women's decision-making and also in the potential and actual patient's decision-making. This research can bring interesting results for other potential comparisons of research or practice.

\section{METHODOLOGY}

In the context of theoretical background and healthcare conditions in the Czech Republic, a list of factors affecting patients' decisions on planned medical services was made. These factors were verified by the pilot study. The final list of factors influencing of the client's decision in the market of health services is as follows:

- Traffic access to workplaces

- The professional reputation of the workplace

- The professional reputation of a specific doctor

- The technical facilities that are available in the workplace 
- The workplace's reputation in terms of empathy and access

- Recommendations from friends and/or relatives

- Referrals from another doctor - i.e. a pediatrician, a geriatrician or a general practitioner

- Shorter waiting times for medical intervention

- The accreditation of medical devices

- The external and internal environments for medical equipment

- The amount of a financial contribution

Many scientific publications deal with decision-making of patients on specific types of planned healthcare. Unfortunately, there is no study that would examine more types of the planned healthcare. The research team analyzed the most frequently presented planned operations offered by various hospitals in the Czech Republic. Based on this analysis, consultation with representatives of healthcare providers and verifying that the pilot study was compiled, the following list of planned surgery includes:

- correction of eye defects,

- aesthetic treatment of the eyelids,

- orthopaedic procedures (total endoprosthesis knee, hip, non-acute arthroscopy of the knee, hip, etc.),

- surgery (planned surgery of the stomach, gallbladder, intestines, etc.), and two special types of planned surgery for women:

- planned childbirth,

- gynaecological surgery.

The research method of quantitative research through a written questionnaire was selected. The target group were clients of selected healthcare services, with an emphasis on pre-defined health services. The data were collected from specialized ambulances (eye ambulances, orthopaedic ambulances, surgical ambulances and gynaecological ambulances) in the period from 1 June 2015 to 31 October 2015. A total number of 795 relevant questionnaires were acquired.

Three research questions were defined:

1. What are the key factors influencing the decision-making process in the market of health services?

2. Is there a difference in perception of the key factors between men and women?

3. Is there a difference in perception of the key factors between potential and real clients?

Two hypotheses were defined:

$\mathrm{H}_{1}$ - According to the respondents participating in the sample, the mean perception of the key factors influencing the decision-making process in the market of health services for males and females is equal.

$\mathrm{H}_{1}: \mu 1-\mu 2=0$ 
$\mathrm{H} 1_{\mathrm{A}}$ - According to the respondents participating in the sample, the mean perception of the key factors influencing the decision-making process in the market of health services for males and females differ.

$\mathrm{H} 1_{\mathrm{A}}: \mu 1-\mu 2 \neq 0$

$\mathrm{H} 2_{0}$ - According to the respondents participating in the sample, there is no difference in the mean perception of the key factors influencing the decision-making process in the market of health services between potential and real clients.

$\mathrm{H} 22_{0}: \mu 3-\mu 4=0$

$\mathrm{H} 2_{\mathrm{A}}$ - The mean perception of the key factors influencing the decision-making process in the market of health services differs between potential and real clients.

$\mathrm{H} 1_{\mathrm{A}}: \mu 3-\mu 4 \neq 0$

For this, the Two-sample t-Test for equal means was used.

The formula for the pooled estimator of $\sigma^{2}$ is

$$
S_{p}^{2}=\frac{\left(n_{1}-1\right) s_{1}^{2}+\left(n_{2}-1\right) s_{2}^{2}}{n_{1}+n_{2}-2}
$$

where s1 and s2 are the standard deviations of the two samples of respondents (men and women, potential and real clients) and $\mathrm{n} 1$ and $\mathrm{n} 2$ are the sizes of the two samples of respondents.

The formula for comparing the means of two populations using pooled variance is

$$
t=\frac{\overline{x_{1}}-\overline{x_{2}}-\Delta}{\sqrt{s_{p}^{2}\left(\frac{1}{n_{1}}+\frac{1}{n_{2}}\right)}}
$$

where equation and equation are the means of the two samples, $\Delta$ is the hypothesized difference between the two samples of respondents ( 0 if testing for equal means), $\mathrm{sp}^{2}$ is the pooled variance, and $n_{1}$ and $n_{2}$ are the sizes of the two samples. The number of degrees of freedom for the problem is

$$
d f=n 1+n 2-2
$$

\subsection{Determination of the sample of respondents}

The specification of the sample is the following:

A sample of 795 pieces was collected in the research and 786 of the questionnaires could be used in the evaluation process (nine questionnaires were excluded because of incomplete information). The relevance of data collection was secured by personal delivery of questionnaires in specialized clinics. The respondents approached were 18 years old. The research sample was divided into six age-groups, according to which the classification of respondents is the following: $21.6 \%$ of respondents were under $30,19.8 \%$ of respondents were between 31 and $40,18.4 \%$ were between 41 and 50,20\% were between 51 and 60; 11.3\% were between 61 and 70, while 9.5 $\%$ of respondents were over 70 years old. According to the highest qualification of respondents, $6.1 \%$ of them finished only primary school, $21.8 \%$ finished apprentice school, $41,8 \%$ had a high school degree, while $30.3 \%$ had a university degree. The survey was completed by 499 
women and 287 men. This is due to the fact that a medical field of gynaecology excludes male respondents (Table 2).

Tab. 2 - Sample characteristics of the primary research (Source: own survey)

\begin{tabular}{|l|l|l|l|}
\hline \multicolumn{2}{|l|}{ Sample characteristics } & $\mathrm{n}$ & $\%$ \\
\hline \multirow{4}{*}{ Gender } & Female & 499 & 63.5 \\
\cline { 2 - 4 } & Male & 287 & 36.5 \\
\hline \multirow{5}{*}{ Education } & Lower than high school & 48 & 6.1 \\
\cline { 2 - 4 } & Apprentice school & 171 & 21.8 \\
\cline { 2 - 4 } & High school degree & 329 & 41.8 \\
\cline { 2 - 4 } & University degree & 238 & 30.3 \\
\hline \multirow{5}{*}{ Age } & Under 30 & 170 & 21.6 \\
\cline { 2 - 4 } & $31-40$ & 156 & 19.8 \\
\cline { 2 - 4 } & $41-50$ & 145 & 18.4 \\
\cline { 2 - 4 } & $51-60$ & 89 & 20 \\
\cline { 2 - 4 } & $61-70$ & 65 & 11.3 \\
\cline { 2 - 4 } & Over 70 & & \\
\hline
\end{tabular}

Concerning the structure of health intervention, we noted that most of the respondents sought medical treatment in orthopaedics $(26.3 \%$ ), followed by planned surgical operations $(19.7 \%)$ and gynaecology $(11.7 \%)$. During the evaluation, it became clear that respondents completed the questionnaire, although they did not seek any medical procedure or other procedures not listed in the questionnaire. Because the answer "other healthcare problems" included a total of 164 respondents, it was necessary to separate those clients who had not even thought about any medical procedure or performance. It was founded that all these respondents had undergone treatment other than that on which our research focuses and for this reason, these questionnaires were evaluated separately. Some respondents addressed more than one health problem, as noted in Table 3.

Tab. 3 - The structure of the healthcare problem (Source: own survey)

\begin{tabular}{|l|l|l|}
\hline Healthcare problem & $\mathrm{n}$ & $\%$ \\
\hline Correction of eye defects & 70 & 8.9 \\
\hline Aesthetic treatment of the eyelids & 37 & 4.7 \\
\hline $\begin{array}{l}\text { Orthopaedic procedures (total endoprosthesis knee, hip, non-acute arthros- } \\
\text { copy of the knee, hip, etc.), }\end{array}$ & 207 & 26.3 \\
\hline Surgery (planned surgery of the stomach, gallbladder, intestines, etc.), & 155 & 19.7 \\
\hline Planned childbirth & 81 & 10.3 \\
\hline Gynaecological surgery & 92 & 11.7 \\
\hline Other problems & 80 & 10.2 \\
\hline Any medical procedure or performance & 84 & 10.7 \\
\hline
\end{tabular}




\section{RESEARCH RESULTS}

The main aim of this research was to determine what key factors influence the decision-making process. The respondents had to assign points from 1 to 11 to the factors of importance, with 1 being the most important one, and 11 the least important ones.

\subsection{Difference between male and female respondents}

The research sample of respondents for the first research - explored the difference in perception of the key factors influencing the decision-making process in the healthcare market between men and women. It consisted of 220 men and 402 women. In the process of statistical analysis, we included only 622 real patients, all of whom dealing with some predefined health problem or problems. The statistical descriptive research sample for all 11 selected factors is presented in Table 4.

Tab. 4 - Group statistics description (Source: own research)

\begin{tabular}{|l|c|c|c|c|c|c|}
\hline \multirow{2}{*}{ Factors } & \multicolumn{3}{|c|}{ Women } & \multicolumn{3}{c|}{ Men } \\
\cline { 2 - 7 } & Mean & St. dev. & Skew & Mean & St. Dev. & Skew \\
\hline Traffic access to workplaces & 6.94118 & 3.51103 & -0.3281 & 7.30233 & 3.46636 & -0.4878 \\
\hline $\begin{array}{l}\text { The professional reputation } \\
\text { of the workplace }\end{array}$ & 3.23155 & 2.40107 & 1.32668 & 3.19159 & 2.26956 & 1.37058 \\
\hline $\begin{array}{l}\text { The professional reputation } \\
\text { of a specific doctor }\end{array}$ & 3.21883 & 2.67985 & 1.26351 & 3.0463 & 2.62682 & 1.48772 \\
\hline $\begin{array}{l}\text { The technical facilities that } \\
\text { are available in the workplace }\end{array}$ & 4.90746 & 2.73987 & 0.54853 & 4.43981 & 2.63714 & 0.64961 \\
\hline $\begin{array}{l}\text { The workplace's reputation in } \\
\text { terms of empathy and access }\end{array}$ & 4.84224 & 2.65644 & 0.39403 & 5.53271 & 2.70044 & 0.16156 \\
\hline $\begin{array}{l}\text { Recommendations from } \\
\text { friends and/or relatives }\end{array}$ & 5.2112 & 2.97673 & 0.26388 & 5.22791 & 2.87743 & 0.38469 \\
\hline $\begin{array}{l}\text { Referrals from another } \\
\text { doctor - i.e. a pediatrician, } \\
\text { a geriatrician or a general } \\
\text { practitioner }\end{array}$ & 4.97959 & 2.76248 & 0.36298 & 5.09302 & 3.04648 & 0.27318 \\
\hline $\begin{array}{l}\text { Shorter waiting times for } \\
\text { medical intervention }\end{array}$ & 6.81888 & 2.90345 & -0.4512 & 6.30698 & 2.88384 & -0.1548 \\
\hline $\begin{array}{l}\text { The accreditation of medical } \\
\text { devices }\end{array}$ & 7.04872 & 3.07911 & -0.4868 & 6.8271 & 2.99969 & -0.3543 \\
\hline $\begin{array}{l}\text { The external and internal } \\
\text { environments for medical } \\
\text { equipment }\end{array}$ & 7.49745 & 2.75514 & -0.7344 & 7.81308 & 2.57518 & -0.8332 \\
\hline $\begin{array}{l}\text { The amount of a financial } \\
\text { contribution }\end{array}$ & 7.4031 & 3.25318 & -0.6574 & 7.85915 & 2.81151 & -0.7519 \\
\hline
\end{tabular}


As mentioned above, the determination of differences in perception of men and women was made by the Two-sample t-Test for equal means. See Table 5 .

Tab. 5 - Two-Sample t-Test for equal means (Source: own research)

\begin{tabular}{|c|c|c|c|c|c|c|c|}
\hline \multirow[t]{2}{*}{ Factors } & \multirow[t]{2}{*}{$\mathrm{T}$} & \multirow[t]{2}{*}{ DF } & \multirow{2}{*}{$\begin{array}{c}\mathrm{P}- \\
\text { value }\end{array}$} & \multirow{2}{*}{$\begin{array}{l}\text { Mean dif- } \\
\text { ference }\end{array}$} & \multirow{2}{*}{$\begin{array}{l}\text { Std. Er- } \\
\text { ror Diff. }\end{array}$} & \multicolumn{2}{|c|}{$\begin{array}{l}\text { Confidence Intervals } \\
\text { for } \mu 1-\mu 2\end{array}$} \\
\hline & & & & & & Lower & Upper \\
\hline $\begin{array}{l}\text { Traffic access to work- } \\
\text { places }\end{array}$ & -1.2215 & 445 & 0.222 & -0.36115 & 0.295 & -0.94221 & 0.21991 \\
\hline $\begin{array}{l}\text { The professional } \\
\text { reputation of the } \\
\text { workplace }\end{array}$ & 0.2030 & 459 & 0.839 & 0.203042 & 0.196 & -0.34682 & 0.42674 \\
\hline $\begin{array}{l}\text { The professional } \\
\text { reputation of a specific } \\
\text { doctor }\end{array}$ & 0.7699 & 450 & 0.441 & 0.172533 & 0.224 & -0.26787 & 0.61293 \\
\hline $\begin{array}{l}\text { The technical facilities } \\
\text { that are available in } \\
\text { the workplace }\end{array}$ & 2.0607 & 458 & 0.039 & 0.46764 & 0.226 & 0.021698 & 0.91358 \\
\hline $\begin{array}{l}\text { The workplace's } \\
\text { reputation in terms of } \\
\text { empathy and access }\end{array}$ & -3.0269 & 431 & 0.002 & -0.69047 & 0.228 & -1.13881 & -0.2421 \\
\hline $\begin{array}{l}\text { Recommendations } \\
\text { from friends and/or } \\
\text { relatives }\end{array}$ & -0.0676 & 453 & 0.946 & -0.01671 & 0.247 & -0.50231 & 0.46888 \\
\hline $\begin{array}{l}\text { Referrals from another } \\
\text { doctor - i.e. a pediatri- } \\
\text { cian, a geriatrician or a } \\
\text { general practitioner }\end{array}$ & -0.4532 & 405 & 0.650 & -0.11343 & 0.250 & -0.60542 & 0.37855 \\
\hline $\begin{array}{l}\text { Shorter waiting times } \\
\text { for medical interven- } \\
\text { tion }\end{array}$ & 2.0865 & 443 & 0.037 & 0.511901 & 0.245 & 0.029746 & 0.99405 \\
\hline $\begin{array}{l}\text { The accreditation of } \\
\text { medical devices }\end{array}$ & 0.8603 & 448 & 0.390 & 0.221615 & 0.257 & -0.28464 & 0.72786 \\
\hline $\begin{array}{l}\text { The external and } \\
\text { internal environments } \\
\text { for medical equipment }\end{array}$ & -1.40661 & 463 & 0.160 & -0.31564 & 0.224 & -0.75659 & 0.12532 \\
\hline $\begin{array}{l}\text { The amount of a fi- } \\
\text { nancial contribution }\end{array}$ & -1.7963 & 492 & 0.073 & -0.45605 & 0.253 & -0.95489 & 0.04277 \\
\hline
\end{tabular}

The two-Sample t-Test for equal means showed the following results. Since the P-values are greater than the significance level (0.05), we cannot reject the null hypothesis for the following eight of eleven total factors: 
1. Traffic access to workplaces

2. The professional reputation of the workplace

3. The professional reputation of a specific doctor

4. Recommendations from friends and/or relatives

5. Referrals from another doctor - i.e. a pediatrician, a geriatrician or a general practitioner

6. The accreditation of medical devices

7. The external and internal environments for medical equipment

8. The amount of a financial contribution

According to respondents participating in the sample, we can confirm the mean perception of the key factors influencing the decision-making process in the market of health services for males and females. It differs for three factors only:

- The technical facilities that are available in the workplace

- The workplace's reputation in terms of empathy and access

- Shorter waiting times for medical intervention

- Technical facilities in the workplace

- Workplace reputation in terms of empathy and access

- Shorter waiting times for health performance

It means that these three factors show differences in perception between men and women.

\subsection{Difference between real and potential patients}

The research sample of respondents for the second part of research - the difference in perception of the key factors influencing the decision-making process in the healthcare market between potential and real clients - consisted of 164 potential clients and 622 real clients. The statistical description research sample for 11 selected factors is shown in Table 6.

Tab. 6 - Group statistics description (Source: own research)

\begin{tabular}{|l|l|l|l|l|l|l|}
\hline \multirow{2}{*}{ Factors } & \multicolumn{3}{|l|}{ Potential patients } & \multicolumn{2}{l|}{ Real patients } \\
\cline { 2 - 7 } & Mean & St. Dev. & Skew & Mean & St. Dev. & Skew \\
\hline Traffic access to workplaces & 6.447 & 3.85085 & -0.1886 & 7.069 & 3.49665 & -0.3827 \\
\hline $\begin{array}{l}\text { The professional reputation of the } \\
\text { workplace }\end{array}$ & 3.136 & 2.56782 & 1.49926 & 3.217 & 2.35374 & 1.33993 \\
\hline $\begin{array}{l}\text { The professional reputation of a } \\
\text { specific doctor }\end{array}$ & 3.279 & 2.70234 & 1.22497 & 3.157 & 2.66028 & 1.33653 \\
\hline $\begin{array}{l}\text { The technical facilities that are } \\
\text { available in the workplace }\end{array}$ & 4.608 & 2.6367 & 0.56912 & 4.740 & 2.71074 & 0.5836 \\
\hline
\end{tabular}




\begin{tabular}{|l|l|l|l|l|l|l|}
\hline $\begin{array}{l}\text { The workplace's reputation in } \\
\text { terms of empathy and access }\end{array}$ & 4.944 & 2.72316 & 0.23818 & 5.085 & 2.69014 & 0.30858 \\
\hline $\begin{array}{l}\text { Recommendations from friends } \\
\text { and/or relatives }\end{array}$ & 5.687 & 2.77044 & 0.19798 & 5.217 & 2.93963 & 0.30279 \\
\hline $\begin{array}{l}\text { Referrals from another doctor } \\
\text {-i.e. a pediatrician, a geriatrician } \\
\text { or a general practitioner }\end{array}$ & 5.137 & 2.84503 & 0.17278 & 5.019 & 2.8643 & 0.33051 \\
\hline $\begin{array}{l}\text { Shorter waiting times for medical } \\
\text { intervention }\end{array}$ & 6.455 & 2.84548 & -0.2875 & 6.637 & 2.90449 & -0.3419 \\
\hline $\begin{array}{l}\text { The accreditation of medical } \\
\text { devices }\end{array}$ & 6.620 & 3.11562 & -0.3176 & 6.970 & 3.05056 & -0.438 \\
\hline $\begin{array}{l}\text { The external and internal envi- } \\
\text { ronments for medical equipment }\end{array}$ & 7.456 & 3.0875 & -0.8246 & 7.608 & 2.69506 & -0.7712 \\
\hline $\begin{array}{l}\text { The amount of a financial contri- } \\
\text { bution }\end{array}$ & 7.696 & 3.21891 & -0.6095 & 7.565 & 3.10889 & -0.7081 \\
\hline
\end{tabular}

To determine the differences in perception of potential and real clients, the Two-sample t-Test for equal means was used. See Table 7.

Tab. 7 - Two-Sample t-Test for equal means (Source: own research)

\begin{tabular}{|l|c|c|c|c|c|c|c|}
\hline Factors & T & DF & $\begin{array}{c}\text { P- } \\
\text { value }\end{array}$ & $\begin{array}{c}\text { Mean } \\
\text { differ- } \\
\text { ence }\end{array}$ & $\begin{array}{c}\text { Std. Er- } \\
\text { ror Dif- } \\
\text { ference }\end{array}$ & \multicolumn{2}{|c|}{$\begin{array}{c}\text { Confidence } \\
\text { Intervals } \\
\text { for } \mu 1-\mu 2\end{array}$} \\
\cline { 5 - 9 } $\begin{array}{l}\text { Traffic access to work- } \\
\text { places }\end{array}$ & -1.864 & 238 & 0.063 & -0.62145 & 0.333394 & -1.278 & 0.0353 \\
\hline $\begin{array}{l}\text { The professional reputa- } \\
\text { tion of the workplace }\end{array}$ & -0.361 & 236 & 0.718 & -0.08082 & 0.223789 & -0.521 & 0.3600 \\
\hline $\begin{array}{l}\text { The professional reputa- } \\
\text { tion of a specific doctor }\end{array}$ & 0.510 & 248 & 0.610 & 0.121868 & 0.238702 & -0.348 & 0.5920 \\
\hline $\begin{array}{l}\text { The technical facilities } \\
\text { that are available in the } \\
\text { workplace }\end{array}$ & -0.560 & 257 & 0.575 & -0.1318 & 0.235217 & -0.595 & 0.3313 \\
\hline $\begin{array}{l}\text { The workplace's reputation } \\
\text { in terms of empathy and } \\
\text { access }\end{array}$ & -0.587 & 249 & 0.557 & -0.14157 & 0.240795 & -0.615 & 0.3326 \\
\hline $\begin{array}{l}\text { Recommendations from } \\
\text { friends and/or relatives }\end{array}$ & 1.886 & 261 & 0.060 & 0.470395 & 0.249366 & -0.020 & 0.9614 \\
\hline $\begin{array}{l}\text { Referrals from another } \\
\text { doctor }\end{array}$ & 0.464 & 250 & 0.642 & 0.117731 & 0.253189 & -0.380 & 0.6163 \\
\hline
\end{tabular}




\begin{tabular}{|l|l|l|l|l|l|l|l|}
\hline $\begin{array}{l}\text { Shorter waiting times for } \\
\text { medical intervention }\end{array}$ & -0.712 & 248 & 0.476 & -0.18187 & 0.255232 & -0.684 & 0.3208 \\
\hline $\begin{array}{l}\text { The accreditation of medi- } \\
\text { cal devices }\end{array}$ & -1.271 & 247 & 0.204 & -0.34976 & 0.275135 & -0.891 & 0.1921 \\
\hline $\begin{array}{l}\text { The external and internal } \\
\text { environments for medical } \\
\text { equipment }\end{array}$ & -0.570 & 226 & 0.568 & -0.15266 & 0,267516 & -0.679 & 0.3744 \\
\hline $\begin{array}{l}\text { The amount of a financial } \\
\text { contribution }\end{array}$ & 0.016 & 239 & 0.987 & 0.00462 & 0.285809 & -0.558 & 0.5676 \\
\hline
\end{tabular}

According to the Two-Sample t-Test for equal means, we must reject the null hypothesis for all factors and must accept that not enough evidence is available to suggest the null is false at the 95\% confidence level. This shows that there are no differences in the perception of the key factors between potential and real clients. The lowest value is for the traffic access to workplaces (p-value 0.0635) and recommendations from friends, relatives, which is the closest factor to approach the critical value of $\mathrm{p}$-value 0.05 .

\section{DISCUSSION AND CONCLUSION}

The results of the research show that in terms of gender, we can find some small differences in preferences of factors. While men chose "The professional reputation of a specific doctor", women considered as the most important factor "The professional reputation of the workplace". The second place, for men, was "The professional reputation of the workplace", while for women it was "The professional reputation of a specific doctor". These factors are in reverse order. In the third place, there are the important technical skills for men and for women, it is the reputation of the workplace in terms of access and their empathy, while for men, this factor is in the fifth place. It is possible to explain this by the fact that, generally speaking, women are both more sensitive and more responsive and therefore, they need more personal and more human approach within a pleasant environment. The least important factors for men were "Traffic access to workplaces", "The external and the internal environment for medical equipment" and "The amount of financial participation". Women chose as the least important factors "The accreditation of medical devices", "The amount of financial participation" and "The external and the internal environment for medical equipment".

Nor have we identified any significant differences between real and potential clients in terms of their preferences. Traffic access to the workplace has experienced the biggest difference in terms of the order of preference factors. Our potential clients ranked it in 7th place in regard to the importance of selecting a healthcare service. For real clients, the factor fell to 9 th place. In regard to most of the factors, the evaluation between potential and real clients was equal, in some cases, only in the reverse order of two consecutive factors.

Using the parameters, certain selected factors of the decision-making process in the market were evaluated on the basis of these values and were then sorted in accordance with their degree of relevance. If we do not take into account the differences that are identified through research, we 
can (for the entire selected sample of respondents) sort out the factors that are influencing the decision-making process in the healthcare market as follows (see Table 8).

Tab. 8 - The rank and value of mean for the key factors influencing the decision-making process in the healthcare market (Source: own research)

\begin{tabular}{|l|l|l|}
\hline Rank & Mean & Factors \\
\hline 1 & 3.200520833 & The professional reputation of the workplace \\
\hline 2 & 3.183116883 & The professional reputation of a specific doctor \\
\hline 3 & 4.71293734 & The technical facilities that are available in the workplace \\
\hline 4 & 5.044328553 & $\begin{array}{l}\text { Referrals from another doctor }- \text { i.e. a pediatrician, a geriatrician } \\
\text { or a general practitioner }\end{array}$ \\
\hline 5 & 5.055989583 & The workplace's reputation in terms of empathy and access \\
\hline 6 & 5.315104167 & Recommendations from friends and/or relatives \\
\hline 7 & 6.6 & Shorter waiting times for medical intervention \\
\hline 8 & 6.896589 & The accreditation of medical devices \\
\hline 9 & 6.937581274 & Traffic access to workplaces \\
\hline 10 & 7.577023499 & The external and internal environments for medical equipment \\
\hline 11 & 7.565963061 & The amount of a financial contribution \\
\hline
\end{tabular}

When we compare these results with Dharmesh and Devendra (2014), we can also say that in these studies, such factors as qualified and experienced doctors, the recognized name of the hospital and a positive word of mouth are amongst the top-ranked. On the contrary, modern equipment and affordable prices were identified as being amongst the least important ones in both studies. In connection with the financial contributions, it was revealed that more than half of the respondents would be willing to pay more for the quality of health care. A larger number of respondents would pay more in total value of CZK 2,000, and the second major part in CZK 5,000 . Most frequently, they would pay more for a specific doctor or surgeon and/or for better material. Therefore, we can conclude that the respondents interviewed recognise that they do have some responsibility for their own health and they are trying to find the limits of their possibilities to ensure that they obtain a better care and sounder material. The differences between the evaluations of the two surveys included the specific importance of access and a convenient location in particular. According to these research results, external clients identified this factor as being the most important whereas in the Czech Republic, it was regarded as the least important, and the clients do not consider travelling to obtain quality medical services as problematic.

The research results raise a number of key questions concerning the patient's choice and its impact on the competitiveness of providers. If organizations want to succeed in the competitive environment in the Czech Republic, they should concentrate on the professional reputation of their workplace and mainly the quality of their doctors. This is very closely related to the typical image of a healthcare organization. It has to continually build its image through communicating with actual and potential clients, publishing interviews with doctors and hospital managements in the press and convincing the client about the quality both of the doctor and of his/her workplace. In 
addition, the organization must focus on the workplace's technical equipment. In terms of communication, it is also necessary to present new equipment and its usage to the public. Moreover, a cooperation with other physicians is very helpful. These can influence client's decision via the recommendation of a particular hospital or of another healthcare organization. The accreditation of a medical device is considered by clients as simply being a normal and indispensable part of service providing. Therefore, it may not be the subject of marketing communication services because a non-accredited medical institution cannot provide medical services. Unlike in other countries, healthcare clients do not consider transport accessibility as a key factor for choosing a healthcare facility in the Czech Republic. Also, the amount of the financial contribution is not important for the client and therefore, it is also not a key factor in regard to the competitiveness of services.

Although it is clear that our research has certain limitations (sample size and the fields of healthcare services), we believe that this article has brought some interesting findings to healthcare organizations for increasing their competitiveness. The potential for future research can be seen in examining the differences between various kinds of planned healthcare; not only in the Czech Republic but also as a comparison between the V4 countries.

\section{Acknowledgements}

The authors are thankful to the Internal Grant Agency IGA/FaME/2015/024 (The key factors influencing decision-making of clients in the market of health services) and Internal Grant Agency RO/2016/12 (Management of healthcare organizations effectiveness) for their financial support in conducting this research.

\section{References}

1. Arora, N. K., \& McHorney, C. A. (2000). Patient preferences for medical decision making: who really wants to participate? Medical care, 38(3), 335-341. http://dx.doi. org/10.1097/00005650-200003000-00010.

2. Boyer, Ch. et al. (2011). Thought leaders project: hospital marketing. USA: Bierbaum Publishing.

3. Burke, E. (2013). The Health Belief Model. Injury Control Council of Western Australia. Retrieved from: http://www.iccwa.org.au/useruploads/files/soyf/2013_resources_videos/ the_health_belief_model.pdfevan_burke.pdf

4. Czech. (2011) Act no. 372/2011 on health services and terms their provision.

5. Callahan, D. (2008). Consumer-directed health care: promise or puffery? Health Economics, Policy and Law, 3 (3), 301-11. http://dx.doi.org/10.1017/S1744133108004490.

6. Dlugacz, Y. D. (2006). Measuring Health Care: Using Data for Operational, Financial, and Clinical Improvement. San Francisco: Jossey-Bass.

7. Dharmesh, M., \& Devendra, S. (2014). Factor Affecting Patients' Decision in Selection of Hospital. Management Strategies Journal, 25(3), 5-10.

8. Dixon, A. et al. (2010). Patient Choice: How Patients Choose and How Providers Respond. London: The King's Fund.

9. Dubey, P., \& Sharma, S. K. (2013). Factors Affecting Choice of Hospital Services in Bilaspur City. International Monthly Refereed Journal of Research In Management and Technology, 97(2)2, 97-104. 
10. Henshaw, E. J., \& Freedmann-Doan, C. R. (2009). Conceptualizing Mental Health Care Utilization Using the Health Belief Model. Clinical Psychology: Science and Practice, 16(4), 420439. http://dx.doi.org/10.1111/j.1468-2850.2009.01181.x.

11. Hunink, M., Weinstein, M.C. et al. (2014). Decision Making in Health and Medicine: Integrating Evidence and Values. Cambridge, United Kingdom: Cambridge University Press. http:// dx.doi.org/10.1017/CBO9781139506779.

12. Institute of Health Information and Statistics of the CR. Czech Health Statistics Yearbook, 1992-2015. Retrieved from: http://www.uzis.cz/en/catalogue/czech-health-statisticsyearbook

13. Karlson, E.W. et al. (1997). Gender Differences in Patient Preferences May Underlie Differential Utilization of Elective Surgery. The American Journal of Medicine, 102(6), 524-530. http://dx.doi.org/10.1016/S0002-9343(97)00050-8.

14. Kinkorová J. \& Topolčan O. (2012). Overview of Healthcare System in the Czech Republic. The EPM A Journal, 3(1), http://dx.doi.org/10.1007/s13167-012-0139-9.

15. Leebow, W. (2012). Customer Service for Professional in Health Care: Key Behaviors That Enhance the Patient and Family Experience. USA: Leebov Golde Group.

16. Soltes, V., \& Gavurova, B. (2014). The functionality comparison of the health care systems by the analytical hierarchy process method. E+ M Ekonomie a Management, 17(3), 100-118. http://dx.doi.org/10.15240/tul/001/2014-3-009.

17. Victoor, A., Delnoij, D. M., Friele, R. D., \& Rademakers, J. J. (2012). Determinants of patient choice of healthcare providers: a scoping review. BMC health services research, 12(1), http://dx.doi.org/10.1186/1472-6963-12-272.

\section{Contact information}

doc. Ing. Staňková Pavla, Ph.D.

Tomas Bata University in Zlin, Faculty of Management and Economics

Mostni 5139, 76001 Zlin, Czech Republic

Email:stankova@fame.utb.cz.

Ing. Horkelová Jana

Tomas Bata University in Zlin, Faculty of Management and Economics Mostni 5139, 76001 Zlin, Czech Republic

Email:horkelovajana@seznam.cz.

Bc. Lučzenskéa Jana

Tomas Bata University in Zlin, Faculty of Management and Economics Mostni 5139, 76001 Zlín, Czech Republic

Email:j.luczewska@centrum.cz.

Bc. Tichá Juliana

Tomas Bata University in Zlin, Faculty of Management and Economics Mostni 5139, 76001 Zlin, Czech Republic

Email:Juliana.Ticha@seznam.cz. 
Bc. Zimǔ́ková Soña

Tomas Bata University in Zlín, Faculty of Management and Economics Mostni 5139, 76001 Zlin, Crech Republic

Email:SonaZimcikova@seznam.cz.

Bc. Cernobila Jan

Tomas Bata University in Zlin, Faculty of Management and Economics Mostni 5139, 76001 Zlin, Crech Republic

Email:jcernobila@gmail.com 